\title{
IN VIVO ANTIOXIDANT AND TOXICITY PROPERTIES OF METHANOL ROOT EXTRACT OF XIMENIA AMERICANA, L. (OLACACEAE) IN DROSOPHILA MELANOGASTER.
}

\author{
Bagu $^{1}$, G. D., Omale ${ }^{1,3}$, S., Iorjiim ${ }^{1}$, W. M., Etu ${ }^{2}$, M. A., Ochala ${ }^{3}$, S. O., Gyang, ${ }^{1}$ S. S., Aguiyi, ${ }^{1,3}$ J. C., \\ ${ }^{1}$ Department of Pharmacology and Toxicology, Faculty of Pharmaceutical Sciences, University of Jos, Nigeria. \\ ${ }^{2}$ Department of Zoology (Applied Entomology and Parasitology), University of Jos, Nigeria. \\ ${ }^{3}$ Africa Centre of Excellence in Phytomedicine Research and Development (ACEPRD), Jos, Nigeria.
}

\begin{abstract}
Antioxidants are chemical molecules that serve as defensive agents in biological systems against the harmful effects of free radicals and are very important in maintaining the optimal function of the body. The antioxidant and toxicity properties of Ximenia americana methanol root extract were investigated using the Drosophila melanogaster model. Findings from the research showed that the extract caused an increase in the activities of all the Oxidative stress biological markers; Catalase, Total thiol, Glutathione-S-transferase, and Superoxide dismutase investigated in a concentrationdependent manner, but the increased observed was not significant $(P>0.05)$ compared to the control. Also, the concentrations $(5 \mathrm{mg}, 20 \mathrm{mg}$, and $60 \mathrm{mg}$ ) used in the studies improved non-significantly $(\mathbf{P}>0.05)$ the survival of the treated groups in $D$. melanogaster when compared to the control. The present study revealed that $X$. americana root is relatively safe and has potent antioxidant activity due to an increased in the activity of the antioxidant enzymes (catalase, Total thiol, Glutathione-S-transferase) by the extract as such can be employed in the management of diseases that are implicated in oxidative stress.
\end{abstract}

Keywords - Antioxidant, Drosophila melanogaster, Free radical, Oxidative stress, Ximenia americana.

\section{INTRODUCTION}

Antioxidants are chemical molecules that protect the biological system against oxidative damage [1]. Oxidative damage are caused by reactive oxygen and nitrogen species(free radicals) generated during normal biological activities in living organisms [2]), [3]. These reactive species have some useful functions within the body of the living things; however, excess concentrations overwhelm the body's immune system thereby causing severe harmful effects [4], [5] . Some of these complications include many processes such as aging and diseases like neurodegenerative disorders, diabetes, cancer, Alzheimer's, dementia, arthritis, Parkinson's, cardiovascular and Huntington's diseases [4]; [6], [7]. The production of these 'free radicals' in the body of humans usually causes an imbalance between pro-oxidant and antioxidant production called 'oxidative stress' [4]. Oxidative stress often leads to irreversible damage to the body cells, proteins, carbohydrates, nucleic acids and lipids [8], [9]. Antioxidant compounds are either endogenous (enzymes/proteins) or exogenous (small molecules like ascorbic acid, carotenoids, tocopherol, flavonoids) in nature and are capable of protecting the human body against damage done by the harmful effect of oxidants [4].

Plant parts like fruits and vegetables are used as foods and in traditional medicine for other purposes including antioxidants in managing some of the above disease conditions [10], [11], [12]. The plant Ximenia americana Linn (Olacaceae), is one of such plants. All parts of the plant (leaves, fruits, seed, stem bark, roots, and root barks) are useful in folk medicine to manage a wide range of diseases [9], [13], [14].

Researchers have reported on the multiple traditional uses of this plant for humans and animals both for food and medicinal purposes. Crushed bark is used for the treatment of hepatitis and malaria. Boiled and filtered pieces of bark in a tea glass were served for treatment of malaria, ulcer, leprosy skin infections and trypanosome congolense [15], [16], [17], [14]. Dried crush bark powder is applied on wound surfaces for the treatment of infected wounds. Dried or fresh stem bark boiled in water is taking orally for treatment of snakebite. Bark is chew to treat swelling pancreas. Also, stem bark has been shown to possess antioxidants activity [18]. The fresh leaves are widely used to treat bloody urine in livestock [19]. Further work on the plant has shown that it has anti-inflammatory activities and is believed to possess antineoplastic and antimicrobial activity [13], [20]. Also, Croke and co-worker 


\section{International Journal of Engineering Applied Sciences and Technology, 2020 \\ Vol. 4, Issue 12, ISSN No. 2455-2143, Pages 59-66 \\ Published Online April 2020 in IJEAST (http://www.ijeast.com)}

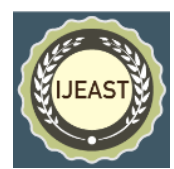

(2017) reported on a wide range of biological activities of $X$. americana. These include antimicrobial, antifungal, antitrypanosomal, antirheumatic, analgesic, molluscicide, pesticidal and also, have hepatic and hematological effects [21]. Similarly, Agyigra et al (2017) reported on the gastroprotective effect of the stem bark of this plant [15].

Additionally, other researchers have reported on the medicinal uses of $X$. americana. The plants' leaves and twigs are used for fever, colds, and treatment of mouth aches, as a laxative, and eye lotion [22]. The roots are used for the treatment of skin problems, abdominal pains, mouth ulcers dysentery, headaches, leprosy, hemorrhoids, edema, sexually transmitted diseases, guinea worm and sleeping sickness [23].

Ximenia americana linn is a tropical plant that belongs to the family Olacaceae, the plant is commonly found in the Sudanese to Guinean Savannahs and African Zones [16], [19]. It is commonly known as wild plum, blue sour plum, Sea Lemon and tallow nut[19]. The plant is spread as a small tree or scrambling spiny shrub that grows up to $6 \mathrm{~m}$ height. Branches normally arching down often armed with straight spines, leaves are simple alternate or clustered on spur shoots with rounded and occasionally softly haired. It has small greenish-white, fragment flowers, born on short shoots and greenish- cream, scented and 5-10 mm long in small, branched inflorescences[24]. Its fruits are oval shiny and are up to $3 \mathrm{~cm}$ long. Light green, turning yellow, orange or red on ripening. The fruit is a yellow-red edible drupe which is oval, approximately $2.5 \mathrm{~cm}$ in diameter and contains one large endospermic seed within its green pulp containing a small embryo near a thin testa. The seeds have up to $65 \%$ oil content. Seeding morphology is variable when young the leaves are densely hairy, but become smooth and shiny with growth [24], [19], [15] .

The fruits of the plants are green but turn golden yellow or red when ripe and when eaten is refreshing and has an almond acid taste. When taken in large quantities act as a vermifuge [18]. A decoction of the roots or fruits is used to treat dysentery in calves [25].

The seeds of Ximenia americana are reported to contain nondrying oil used in soap manufacture and lubrication [25] and is used traditionally in a country like Ethiopia to soften leather. Also, there was a documented report on the use of the extracted oil from the plant seeds by women in Ethiopia as a contraceptive and medically the oil is used in the treatment of hepatitis, kidney problem and abdominal pain [19].

The antioxidant and toxicity properties of parts of the plant have been carried out using different animal models[18], [26], [9], however, this is the first time of using Drosophila melanogaster (Fruit Fly) model to investigate the toxicity and antioxidant activities of the root of the plant.
Drosophila melanogaster (Fruit Fly) is a very reliable and useful model in carrying out biological assays. It belongs to the genus 'Drosophila' (dew lover), species 'melanogaster' (dark gut). Its classification includes; domain eukaryote, kingdom Animalia, phylum Arthropoda, class Insecta and order Diptera.

The Fruit Fly model has many advantages over vertebrate models. These include the ease and inexpensive of breeding in laboratory conditions, have a shorter life cycle i.e. they breed quickly (8-14 days) depending on the temperature and relative humidity, they produce large numbers of externally laid embryos, they can be genetically modified [27] in numerous ways and they have only four pair of chromosomes which can be easily manipulated. Also, they can be found on all continents, including Islands. D. melanogaster is a common pest in homes, restaurants, and in other places where foods and fruits are serves, it is often referred to as 'Vinegar Fly' [28], [3], [29], [30].

\section{MATERIALS AND METHODS}

\subsection{Materials}

\subsection{Plant collection and identification}

The roots of the plant Ximenia americana were collected in Makabun Village in Kaura Local Government Area, Kaduna State, Nigeria. The plant was identified by a plant taxonomist Mr. J. J. Azila of Federal College of Forestry Jos, Plateau State Nigeria, voucher number FHJ 243 was deposited at the herbarium of the college.

The plant roots were washed with clean water, the outer scale carefully removed and air-dried at room temperature, then pulverized manually using wooden mortar and pestle. The powdered sample was stored at $4^{\circ} \mathrm{c}$ in an airtight container and properly labeled for further work.

\subsection{Drosophila stock, reagents, and equipment}

Drosophila melanogaster stock (Harwich strain) each sex was used, analytical grade methanol (CAS: 67-56-1, Lot: 1214788) by Fisher scientific UK, Eppendorf centrifuge 5427 R, Jenway 7315 UV- Spectrophotometer, Analytical weigh balance, rotary evaporator (RE-52A by PEC MEDICAL USA). All other solutions, reagents, and buffers used were prepared using glass wires and distilled water.

\subsection{Methods}

\subsection{Extraction of plant material (Using $70 \% \mathrm{v} / \mathrm{v}$ Methanol)}

The dried powder plant material was extracted in $70 \%$ Methanol by cold maceration in ratio 1: 10 (Solute to Solvent) for 72 hours using an amber bottle with intermittent shaking. At the end of the $72 \mathrm{~h}$, the crude methanol extract was filtered using Whatman No1 and the filtrate concentrated in a rotary evaporator and dried using a free dryer. The dried extract was used to carry out phytochemical, toxicity and antioxidant 


\section{International Journal of Engineering Applied Sciences and Technology, 2020 \\ Vol. 4, Issue 12, ISSN No. 2455-2143, Pages 59-66 \\ Published Online April 2020 in IJEAST (http://www.ijeast.com)}

activity of Ximenia americana using the Drosophila Melanogaster model.

\subsection{Phytochemical tests}

Chemical tests were employed for the preliminary phytochemical screening of the plant secondary metabolites. The dried powdered extract of the methanol root was used to test for Alkaloids, Saponins, Tannins, Anthraquinones, Flavonoids, Cardiac glycosides, carbohydrate, steroids and terpenoids using established protocols described by [31], [12], [32].

\subsection{In vivo antioxidant assay}

Graded concentrations (5 mg, $20 \mathrm{mg}$, and $60 \mathrm{mg}$ ) of the methanol root extract of $X$. americana was administered to randomly selected fruit flies (50) of both genders via oral route by incorporating into the fly food $(10 \mathrm{~g})$ for 7 days. Concentrations were prepared by dissolving the weighed dried plant extract in $1 \mathrm{ml}$ distilled water. Control was prepared by adding $1 \mathrm{ml}$ distilled water into $10 \mathrm{~g}$ food. Each experimental assay has 5 replicates. At the end of the day 7, both treated (exposed) and untreated (control) flies were harvested in cleaned dried disinfected vails (label appropriately) on light ice anesthesia, weighed and homogenized using $0.1 \mathrm{M}$ phosphate buffer saline (BPS), $\mathrm{pH} 7.0$ and centrifuged using Eppendorf centrifuge $5427 \mathrm{R}$ at $4000 \mathrm{rpm}$ for $10 \mathrm{~min}$ at $4^{0} \mathrm{C}$. The supernatant(homogenate) collected was employed in determining the activities of Catalase (CAT), Glutathione-Stransferase (GST), Superoxide Dismutase (SOD) and Total thiol as biomarkers of oxidative stress according to existing protocols.

\subsection{Estimation of catalase (CAT) activity}

Catalase activity (EC 1.11.1.6) was assayed spectrophotometrically according to the method of Aebi, 1984 with little modification. The protocol involved monitoring the disappearance of $\mathrm{H}_{2} \mathrm{O}_{2}$ in a reaction mixture. Briefly, the reaction medium contained $1800 \mu \mathrm{l}$ of $50 \mathrm{mM}$ phosphate buffer saline ( $\mathrm{pH} \mathrm{7.0),} 180 \mu \mathrm{l}$ of $300 \mathrm{mM} \mathrm{H}_{2} \mathrm{O}_{2}$, and $20 \mu \mathrm{l}$ of the sample (1:10 dilution). The reaction was running for 120 Seconds (10 seconds interval) at $240 \mathrm{~nm}$ using Jenway 7513 UV- visible spectrophotometer. The control mixture containing: $50 \mathrm{mM}$ phosphate buffer $(\mathrm{pH} \mathrm{7.0)}$ ) and $0.1 \mathrm{ml}$ of the cell homogenate. The activity of CAT was expressed as $\mathrm{mmol}$ of $\mathrm{H}_{2} \mathrm{O}_{2}$ consumed $/ \mathrm{min} / \mathrm{mg}$ protein [33].

2.26 Estimation of glutathione - S-transferase (GST) activity

Glutathione is a tripeptide (L-y-glutamyl-L-cysteinyl-glycine) amino acid and has multiple cellular functions in living things [34]. It has a carrier potent thiol group in the form of cysteine residue as such act as an antioxidant [35] directly by interacting with reactive species (free radicals) and electrophiles or indirectly by operating as a cofactor for different enzymatic reactions [36], [37].

Glutathione -S- transferase activity was assayed according to the method previously described by Habig and Jakoby with little modification, using 1-chloro-2, 4-dinitrobenzene
(CDNB) serves as the substrate. The reaction mixture consisted of $270 \mu \mathrm{l}$ of the solution containing $(20 \mathrm{~mL}$ of 0.25 $\mathrm{M}$ potassium phosphate buffer, $\mathrm{pH} 7.0,10.5 \mathrm{~mL}$ of distilled water, and $500 \mu \mathrm{l}$ of $0.1 \mathrm{M} \mathrm{GSH}$ at $25^{\circ} \mathrm{C}$ ), $20 \mu \mathrm{l}$ of the sample (1:5 dilution), and $10 \mu \mathrm{l}$ of $25 \mathrm{mM}$ CDNB. The reaction was analyzed for 2 minutes (10 seconds intervals) at $340 \mathrm{~nm}$ in a Jenway 7315 UV Spectrophotometer. The activity of GST was expressed in $\mathrm{mmol} / \mathrm{min} / \mathrm{mg}$ protein using the molar extinction coefficient $(\varepsilon)$ of $9.6 \mathrm{mM}^{-1} \mathrm{~cm}^{-1}$ for CDNB conjugate [38].

\subsection{Estimation of superoxide dismutase (SOD) activity}

Superoxide dismutase is a major cellular enzyme that dismutase reactive oxygen species (ROS) 'superoxide' into hydrogen peroxide and oxygen by the reaction;

$$
2^{-} \mathrm{O}_{2}{ }^{*}+2 \mathrm{H}^{+} \rightarrow \mathrm{H}_{2} \mathrm{O}_{2}+\mathrm{O}_{2}
$$

The level of SOD activity was determined by the method previously described by Misra and Fridovich (1972). The ability of the enzyme to inhibit the oxidation of the substrate in the reaction mixture was read at $418 \mathrm{~nm}$ using spectrophotometer (Jenway 7315 UV Spectrophotomete) at 30 second interval for 120 seconds [1].

\subsection{Estimation of total thiol level}

The total thiol level was determined in both the control and exposed flies according to the method previously described by Ellman, (1959) with little modification. The reaction system was made up of $510 \mu \mathrm{l}$ of $0.1 \mathrm{M}$ PBS ( $\mathrm{pH} 7.4), 25 \mu \mathrm{l}$ of the sample, and $30 \mu \mathrm{l}$ of $10 \mathrm{mM}$ DTNB. At the end of 30 minutes incubation at room temperature $\left(25^{\circ} \mathrm{C}\right)$, the change in absorbance was measured at $412 \mathrm{~nm}$ using Janeway $7315 \mathrm{UV}$ spectrophotometer. A standard curve was plotted for each measurement using GST (35 $\mu \mathrm{l})$ as a standard, the results were expressed as $\mu \mathrm{mol} / \mathrm{mg}$ protein [39].

\subsection{Statistical analysis}

Results obtained from biochemical assay were analyzed using Analysis of Variance (ANOVA) followed by Turkey's posthoc test to identify differences between test groups [Graphpad prism version 8.0.2 (263)]. Results were expressed as the standard error of the mean $( \pm \mathrm{SEM}), P<0.05$ was considered statistically significant.

\section{RESULTS AND DISCUSSION}

Results from the phytochemical screening of the methanol root extract of the plant showed the presence of tannins, flavonoids, cardiac glycosides, steroids, carbohydrates and anthraquinones (Table 1). Plants that have phenols and polyphenols constituents like flavonoids and tannins have been previously reported to possess both antioxidant, Iron 


\section{International Journal of Engineering Applied Sciences and Technology, 2020 \\ Vol. 4, Issue 12, ISSN No. 2455-2143, Pages 59-66 \\ Published Online April 2020 in IJEAST (http://www.ijeast.com)}

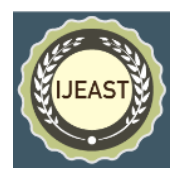

chelating and anti-inflammation activities [18], [40], [41], [42], [43]. The presence of these plant secondary metabolites in $X$. americana methanol extract may be a possible reason for its anti-oxidative stress activity. Similarly, the extract revealed the presence of Anthraquinones, a plant secondary metabolite that has been reported to have anti-cancer, antiinflammatory, antimicrobial, diuretic, vaso-relaxant, and phytoestrogen properties, suggesting their useful application clinically [44].

\subsection{Seven days survival assay}

The percentage of flies ' survival increased with an increase in the concentration of the plant extract, with the higher survival observed with $60 \mathrm{mg}$ when compared to the control (Fig.1). This result showed the possible protective benefit of $X$. americana as used by traditional medicinal practitioners, hence its extract increased the survival of treated fly when compared to untreated. The difference between the two experimental groups (treated and untreated) was not significant $(P>0.05)$ statistically.

\subsection{Catalase (CAT) activity}

The activity of catalase enzyme occurs in the second phase of the dismutation reaction that aimed at scavenging hydrogen peroxide $\left(\mathrm{H}_{2} \mathrm{O}_{2}\right)$ free radical anions into $\mathrm{H}_{2} \mathrm{O}$ and $\mathrm{O}_{2}$ especially in the electron transport system in animal cells (com). Thus, CAT activity can be referred to as 'dismutation of hydrogen peroxides'

$$
\mathrm{H}_{2} \mathrm{O}_{2}+\mathrm{H}_{2} \mathrm{O}_{2} \rightarrow 2 \mathrm{H}_{2} \mathrm{O}+\mathrm{O}_{2}
$$

Our result showed a non-significant $(P>0.5)$ increase in catalase activity in a concentration-dependent manner in the exposed flies when compared to the control. The highest activity was observed with $60 \mathrm{mg}$ and lowest with the $5 \mathrm{mg}$ concentrations (Fig. 2). This result has shown that at the concentrations of the extract used in this work, $X$. americana exhibits antioxidant activity by elevation of CAT activity and hence may help counteract the harmful effect of this free radical species (ROS) by converting $\left(\mathrm{H}_{2} \mathrm{O}_{2}\right)$ into water and oxygen. This result is in agreement with Maikai and coworker 2010, who demonstrated by in vitro method the antioxidant activity of stem bark of this plant [18], [9],[45] , [46], [47], [48], [26], [49].

\subsection{Total thiol and glutathione-S-transferase (GST) activities}

Thiols generally are organic molecules that contain sulfhydryl groups (-SH) and constitute a major antioxidant fraction that helps detoxified free radicals in the human body [8]. Total thiols are made up of both intracellular (e.g. Glutathione, thioredoxin) and extracellular thiols (e.g. albumin) that exist both in the free form (oxidized or reduced glutathione), or thiols in plasma proteins [8]. Besides their role in free-radical defense, thiols also serve in signal transduction during communication, apoptosis and other numerous functions at the molecular level [50], [3] . The status of these organic compounds in the body is an indicator of its antioxidant efficacy. Our results indicated a serial increase in the total thiol with increased concentration $(5 \mathrm{mg}, 20 \mathrm{mg}$, and $60 \mathrm{mg}$ ) of the extract when compared with the control. However, the difference was not statistically significant $(p>0.05)$ (Fig. 3). Also, the activity of GST increases with concentration from lower to higher. GST activity observed with the higher concentration $(60 \mathrm{mg})$ is more than the control but the differences is not significant $(P>0.05)$ (Fig. 4). These findings indicated that methanol root extract of $X$. americana is capable of improving both the total thiol content and GST activity in treated Drosophila melanogaster and possibly have some in vivo antioxidant protective activity in this model.

\subsection{Superoxide dismutase (SOD) activity}

SOD is the major enzyme that helps the body systems to destroy the very destructive ROS 'superoxide' into weak ROS 'hydrogen peroxide' and 'water' in the reaction below [51],

$$
2{ }^{*} \mathrm{O}_{2}^{-}+2 \mathrm{H}^{+} \rightarrow \mathrm{H}_{2} \mathrm{O}_{2}+\mathrm{O}_{2}
$$

In the above reaction, SOD initiates the conversion of two superoxide anions into a molecule of hydrogen peroxide $\left(\mathrm{H}_{2} \mathrm{O}_{2}\right)$ and oxygen $\left(\mathrm{O}_{2}\right)$, this is the initial step is cooping free radicals. Our findings show the level of enzyme (SOD) activity decreased (indicative of autoxidation of substrate) with increased concentration of the tested extract in the exposed groups. whereas, its level of activity is more in the non-treated group. (Fig. 5). The observed difference was not statistically significant $(P>0.05)$. This demonstrated that the methanol plant extract has activity against the free radical generated by the substrate(epinephrine) in the reaction mixture.

Table 1. Phytochemical constituents of Ximenia americana methanol root extract

\begin{tabular}{ll}
\hline Phytochemical constituents & Results \\
\hline Tannins & + \\
Flavonoids & + \\
Carbohydrates & + \\
Steroids & + \\
Anthraquinones & + \\
Cardiac Glycosides & + \\
Alkaloids & - \\
Saponins & - \\
Terpenoids & - \\
\hline
\end{tabular}

KEY : + = present, - = absent. 
International Journal of Engineering Applied Sciences and Technology, 2020

Vol. 4, Issue 12, ISSN No. 2455-2143, Pages 59-66

Published Online April 2020 in IJEAST (http://www.ijeast.com)

Total Thiol

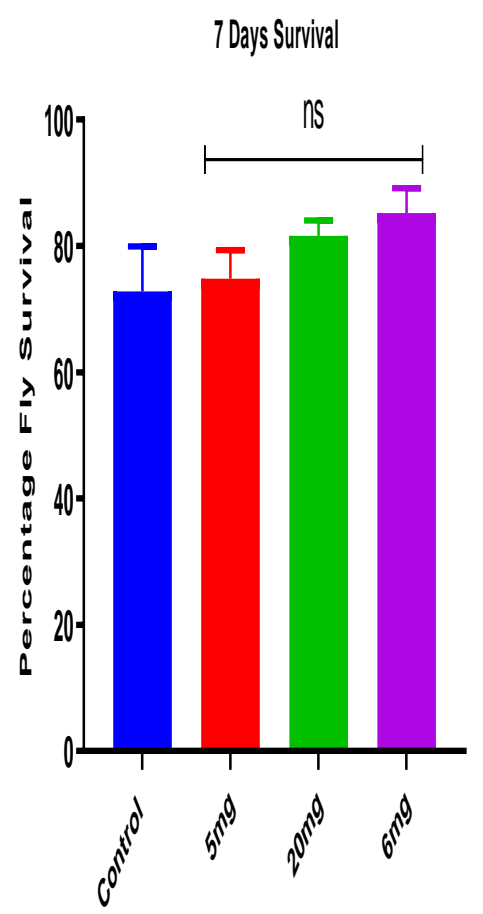

Fig. 1.7 Days sly survival on X, americana methanol methanol root extriacion treated and control.

The percentage of flly survival slighty increased with concentration, but the increase was not significantly different $(\mathrm{B} 0.05)$ when compared to the control.

ns= not significant

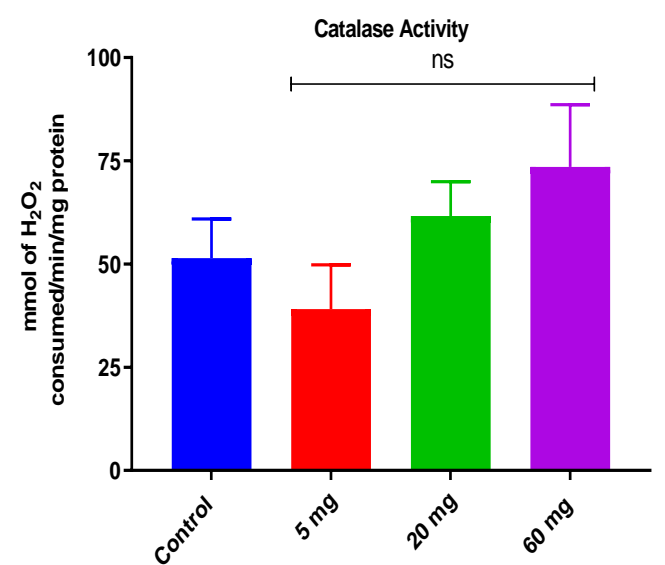

Fig 2. CAT activity of $X$. americana methanol root extract in treated and control flies. the activities increase with concentration but not significant compared to the control $(P>0.05)$. $\mathrm{ns}=$ not significant

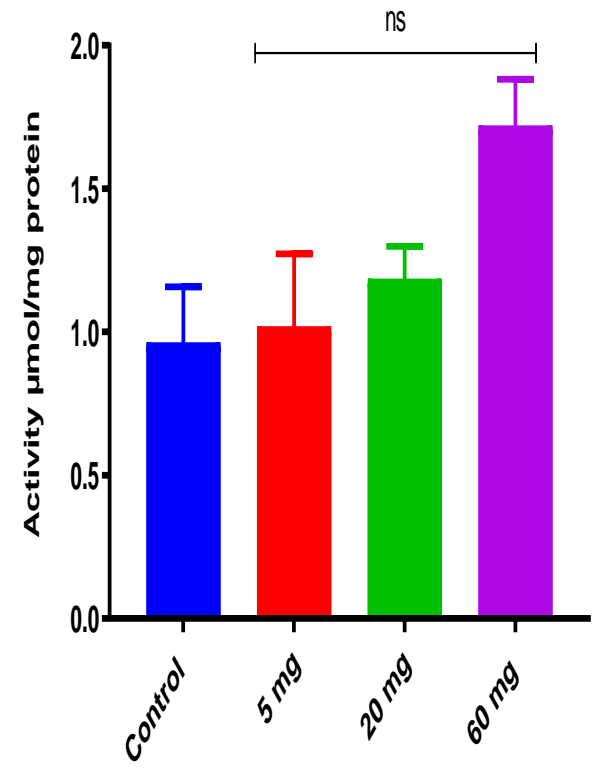

Fig. 3. Total thiol content of $X$. emericana methanol root extract on treated and control flies. The increase in total thiol content of the extract was not significantly different $(P>0.05)$ when compared to the control. ns= not significant.

\section{CONCLUSION}

A careful study of our results above showed that the plant $X$. americana has useful phytochemicals that have been established to possess antioxidant activity, and are employed in the management of certain disease conditions (e.g. Atherosclerosis, Cancer, Pulmonary dysfunction, Cataracts, Arthritis, Diabetes, Shock, trauma, renal diseases, and inflammatory diseases). Also, the chosen concentration of methanol root extract of $X$. americana in our current study demonstrate some level of safety observed by slight increased survival, increase total thiol content, CAT and GST activities as well as decreased SOD in D. melanogaster. These results put together suggest that methanol root extract of $X$. americana plant can counteract free radical that is generated during normal redox activity and diseased states in living things. Therefore, we concluded that using the $D$. melanogaster model, the methanol root extract of $X$. 


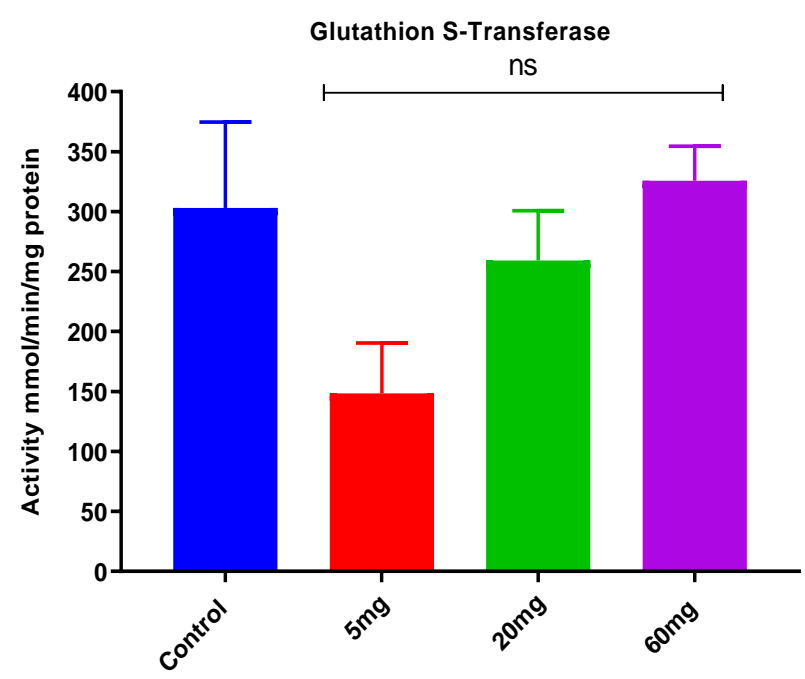

Fig. 4. GST activity of $X$. americana methanol root extract on treated and control fifes. Activity of GST increased with concentration but the increase was not significant $(P>0.05)$. ns=not significant

things. Therefore, we concluded that using the $D$. melanogaster model, the methanol root extract of $X$. americana is safe and has antioxidant activities and may be of benefit in managing illnesses that are associated with it.

\subsection{Competing interest}

We declare that there is no competing interest what so ever in carrying out this work.

\subsection{Acknowledgments}

We acknowledge the African Centre of Excellence in Phytomedicine Research and Development headed by Prof. C.J. Aguiyi, for granting permission to used her facility for this research work \& the Drosophila Research team at the center for their technical assistance. We equally acknowledge the contribution of Mr. Daniel Shailong of the Biochemistry Division of National Veterinary Research Institute (NVRI) Vom, Jos, Nigeria for analysis of SOD.

\subsection{Authors' contributions}

Conceived and design the experiment: Great, David Bagu. Performed the benchwork: Great, David Bagu. Assisted in performed benchwork: Etu, Monday Alexander. Benchwork supervisor: Omale, Simeon. Project supervisor: Steven, Samuel Gyang. Analysis: Great, David Bagu. Read proof and arrangement; Iorjiim, Walter Mdekera and Omale, Simeon. Approval for bench work; John, Chiyere Aguiyi. Technical assistance; Ochala, Sunshine Ogwu.

\section{REFERERENCE}

1. H. P. Misra and I. Fridovich, "The role of superoxide anion in the autoxidation of epinephrine and a simple assay for superoxide dismutase.," J. Biol. Chem., vol. 247, no. 10, pp. 3170-3175, 1972.

2. J. P. Kehrer, J. D. Robertson, and C. V. Smith, "Free Radicals and Reactive Oxygen Species," Compr. Toxicol. Second Ed., vol. 1-14, pp. 277-307, 2010.

3. E. M. Alexander et al., "The In vivo Antioxidant Protective Activity of Mangifera indica Cold Aqueous Leaf Extract in Drosophila Melanogaster," J. Adv. Biol. Biotechnol., vol. 22, no. 2, pp. 1-7, 2019.

4. M. Percival, "Antioxidant," Clin. Nutr. INSIGHTS, pp. 1-4, 1998.

5. M. Assady, A. Farahnak, A. Golestani, and M. Esharghian, "Superoxide Dismutase (SOD) Enzyme Activity Assay in Fasciola spp. Parasites and Liver Tissue Extract," Iran. J Parasitol, vol. 6, no. 4, pp. 17-22, 2011.

s. A. Cohen and P. Horak, "How to measure oxidative stress in an ecological context: methodological and statistical issues," Funtional Ecol., vol. 24, pp. 960970, 2010.

7. H. Paul, "An Introduction to Reactive Oxygen Species Measurement of ROS in Cells," BioTek Instruments, Inc., pp. 1-21, 2015.

8. V. I. Lushchak, "Glutathione Homeostasis and Functions: Potential Targets for Medical Interventions," J. Amino Acids, vol. 2012, pp. 1-26, 2011.

9. V. T. Uchôa et al., "Free radical scavenging ability of Ximenia americana L . stem bark and leaf extracts," J. Appl. Pharm. Sci., vol. 6, no. 02, pp. 091-096, 2016.

10. C. M. Ogunyemi, A. A. Elujoba, and M. A. Durosinmi, "Antisickling Properties of Carica papaya Linn.," J. Nat. Prod., vol. 1, no. 2008, pp. 56-66, 2008.

11. S. K. Adesina, "THE NIGERIAN ZANTHOXYLUM; CHEMICAL AND BIOLOGICAL VALUES," Afri. J. Tradit. Complement. Altern. Med., vol. 2, no. 3, pp. 282301, 2005.

12. A. Sofowora, E. Ogunbodede, and A. Onayade, "THE ROLE AND PLACE OF MEDICINAL PLANTS IN THE STRATEGIES FOR DISEASE PREVENTION," Afr J Tradit Complement Altern Med, vol. 10, no. 5, pp. 210-229, 2013.

13. D. S. Ogunleye and S. F. Ibitoye, "Studies of antimicrobial activity and chemical constituents of Ximenia americana," Trop. J. Pharm. Reseasrch, vol. 2, no. 2, pp. 239-241, 2003.

14. T. O. Olanrewaju, P. O. Odumosu, and K. O. Eyong, "Anti-trypanosomal evaluation of Ximenia americana root bark and chromatographic-mass spectrometric profile GSC Biological and Pharmaceutical Sciences Anti-trypanosomal evaluation of Ximenia americana 


\section{International Journal of Engineering Applied Sciences and Technology, 2020 \\ Vol. 4, Issue 12, ISSN No. 2455-2143, Pages 59-66 \\ Published Online April 2020 in IJEAST (http://www.ijeast.com)}

root bark and chromatographic -mass spectrometric profi," GSC Biol. Pharm. Sci., vol. 07, no. 02, pp. 108-117, 2019.

15. A. I. Agyigra, J. I. Ejiofor, M. G. Magaji, and Y. Yakubu, "Evaluation of Methanol Stem-bark Extract of Ximenia americana Linn ( Olacaceae ) for Phytoconstituents and Gastroprotection in Rats," African J. Pharmacol. Ther., vol. 6, no. 4, pp. 161165, 2017.

16. A. alfatah Abd alla, S. L. Shyaula, C. Y. Ishak, and S. M. H. Ayoub, "Bioassay and Phytochemical Studies on Ximenia Americana L . Bark Ethanolic Extract," J. For. Prod. Ind., vol. 2, no. 3, pp. 63-68, 2013.

17. A. A. Adeiza and M. N. Salka, "Effects of methanol extract of Ximenia americana on sexual behaviour, testicular weight, sperm count and sperm morphology of wister rats," Ann. Biol. Res., vol. 2, no. 1, pp. 107113, 2011.

18. V. A. Maikai, P. I. Kobo, and B. V. O. Maikai, "Antioxidant properties of Ximenia americana," African J. Biotechnol., vol. 9, no. 1612, pp. 77447746, 2010.

19. D. H. Feyssa, J. T. Njoka, Z. Asfaw, and N. M. M, "USES AND MANAGEMENT OF XIMENIA AMERICANA , OLACACEAE IN SEMI-ARID EAST SHEWA , ETHIOPIA," Pak. J. Bot, vol. 44, no. 4, pp. 1177-1184, 2012.

20. Q. F. Liu et al., "In Vivo Screening of Traditional Medicinal Plants for Neuroprotective Activity against A $\beta 42$ Cytotoxicity by Using Drosophila Models of Alzheimer' s Disease," Bio. Pharm. Bull, vol. 38, no. 12, pp. 1891-1901, 2015.

21. K. Croke et al., "Relationships between sickle cell trait, malaria, and educational outcomes in Tanzania," BMC Infect. Dis., vol. 17, no. 568, pp. 16, 2017.

22. J. Abbink, "ME' EN RITUAL, MEDICINAL AND OTHER PLANTS: A CONTRIBUTION TO SOUTH-WEST ETHIOPIAN ETHNO-BOTANY," J. Ethopian Stud., vol. 26, no. 2, pp. 1-21, 1993.

23. V. A. Maikai, P. I. Kobo, and A. O. Adaudi, "Acute toxicity studies of aqueous stem bark extract of Ximenia americana," African J. Biotechnol., vol. 7, no. 10, pp. 1600-1603, 2008.

24. M. Sacande and H. Vauteir, "Ximenia americana L.," Seed Leafl., vol. 112, pp. 1-3, 2006.

25. Orwa, "Ximenia americana L.," Agrofor. Database 4.0, vol. 29, no. 03, pp. 1-5, 2009.

26. J. Darcio et al., "Physical-chemical characteristics and antioxidant potential of seed and pulp of Ximenia americana L . from the semiarid region of Brazil," African J. Biotechnol., vol. 14, no. 20, pp. 1743$1752,2015$.

27. M. Sonoshita and R. L. Cagan, Modeling Human Cancers in Drosophila, 1st ed., vol. 121. Elsevier
Inc., 2016.

28. P. S. Bosch et al., "Blood cells of adult drosophila do not expand, but control survival after bacterial infection by induction of Drosocin around their reservoir at the respiratory epithelia," bioRxiv, 2019.

29. A. O. Abolaji et al., "Ovotoxicants 4vinylcyclohexene 1,2-monoepoxide and 4vinylcyclohexene diepoxide disrupt redox status and modify different electrophile sensitive target enzymes and genes in Drosophila melanogaster," Redox Biol., vol. 5, no. 2015, pp. 328-339, 2015.

30. D. Francis and A. S. Ghabrial, "Compensatory branching morphogenesis of stalk cells in the Drosophila trachea," Development, vol. 142, pp. 2048-2057, 2015.

31. G. E. Trease and W. C. Evans, Pharmacognosy. 2009.

32. G. Cooper-Driver and J. B. Harborne, Phytochemical Methods, vol. 29, no. 4. 1973.

33. H. Aebi, "[13] Catalase in Vitro," Methods Enzymol., vol. 105, no. C, pp. 121-126, 1984.

34. H. Sies, "GLUTATHIONE AND ITS ROLE IN CELLULAR FUNCTIONS," Free Radic. Biol. Med., vol. 27, no. 7/10, pp. 916-921, 1999.

35. A. Śliwa-jóźwik, A. Jóźwik, W. Fronczyk, A. Guszkiewicz, and A. Kołątaj, "Effect of reduced glutathione ( GSH ) on activity of lysosomal system in subcellular fractions of mouse kidney," Anim. Sci. Pap. Reports, vol. 22, no. 2, pp. 237-245, 2004.

36. P. Zhuo et al., "Molecular Consequences of Genetic Variations in the Glutathione Peroxidase 1 Selenoenzyme," Cancer Res., vol. 69, no. 20, pp. 8183-8191, 2009.

37. M. S. Pittman, H. C. Robinson, and R. K. Poole, "A Bacterial Glutathione Transporter ( Escherichia coli CydDC ) Exports Reductant to the Periplasm *," J. Biol. Chem., vol. 280, no. 37, pp. 32254-32261, 2005.

38. C. J. Marcus, W. H. Habig, and W. B. Jakoby, "Glutathione transferase from human erythrocytes. Nonidentity with the enzymes from liver," Arch. Biochem. Biophys., vol. 188, no. 2, pp. 287-293, 1978.

39. G. L. Ellman, "Tissue Sulfhydryl Groups," Arch. Biochem. Biophys., vol. 82, no. 1, pp. 70-77, 1959.

40. [40] S. Kumar and A. K. Pandey, "Flavonoidi," Sci. World J., vol. 2013, pp. 1-17, 2013.

41. K. T. Chung, T. Y. Wong, C. I. Wei, Y. W. Huang, and Y. Lin, "Tannins and human health: A review," Crit. Rev. Food Sci. Nutr., vol. 38, no. 6, pp. 421464, 1998.

42. S. Kumar, A. Gupta, and A. K. Pandey, "Calotropis procera Root Extract Has the Capability to Combat Free Radical Mediated Damage ," ISRN Pharmacol., vol. 2013, pp. 1-8, 2013. 


\section{International Journal of Engineering Applied Sciences and Technology, 2020 \\ Vol. 4, Issue 12, ISSN No. 2455-2143, Pages 59-66 \\ Published Online April 2020 in IJEAST (http://www.ijeast.com)}

43. M. Leopoldini, N. Russo, S. Chiodo, and M. Toscano, "Iron chelation by the powerful antioxidant flavonoid quercetin," J. Agric. Food Chem., vol. 54, no. 17, pp. 6343-6351, 2006.

44. S. C. Chien, Y. C. Wu, Z. W. Chen, and W. C. Yang, "Naturally occurring anthraquinones: Chemistry and therapeutic potential in autoimmune diabetes," Evidence-based Complement. Altern. Med., vol. 2015, pp. 1-13, 2015.

45. K. Kiessoun et al., "ANTIMICROBIAL PROFILES, ANTIDIARRHEAL AND ANTIPYRETIC CAPACITIES OF PHENOL ACID RICHFRACTIONS FROM XIMENIA AMERICA L ., ( OLACACEAE ) IN WISTAR ALBINO RATS," Int. J. Pharm. Pharm. Sci., vol. 10, no. 10, pp. 61-68, 2018.

46. G. F. Sousa Carvalho et al., "Phytochemical study, molecular docking, genotoxicity and therapeutic efficacy of the aqueous extract of the stem bark of Ximenia americana L. in the treatment of experimental COPD in rats," J. Ethnopharmacol., vol. 247, no. 2020, pp. 1-12, 2019.

47. N. H. T. Le, K. E. Malterud, D. Diallo, B. S. Paulsen, C. S. Nergård, and H. Wangensteen, "Bioactive polyphenols in Ximenia americana and the traditional use among Malian healers," J. Ethnopharmacol., vol. 139, no. 2012, pp. 858-862, 2011.

48. F. José, Q. Monte, T. Leda, and G. De Lemos, Ximenia americana: Chemistry, Pharmacology and Biological Properties, a Review. 2008.

49. M. Mariko, S. O. Sarr, A. Diop, I. A. Modi, B. Dackouo, and Y. M. Diop, "Antioxidant activity study and total phenolic determination of leaf extracts of Ximenia americana L. (Olacaceae) an anti-tumor plant used traditionally in Mali," J. Appl. Biosci., vol. 106, pp. 10258-10265, 2016.

50. M. Prakash, M. S. Shetty, P. Tilak, and N. Anwar, "Review Total Thiols: Biomedical Importance And Their Alteration In Various Disorders Authors Glutathione: Protein Thiols:," J. Heal. Allied Sci., vol. 8, no. 2, pp. 1-9, 2009.

51. C. J. Weydert and J. J. Cullen, "Measurement of superoxide dismutase, catalase and glutathione peroxidase in cultured cells and tissue," Nat. Protoc., vol. 5, no. 1, pp. 51-66, 2010. 